\title{
Transient Analyses for the Tajoura Critical Facility with IRT-2M HEU Fuel and IRT-4M LEU Fuel: ANL Independent Verification Results
}

prepared by

Nuclear Energy Division

Argonne National Laboratory 


\section{About Argonne National Laboratory}

Argonne is managed by The University of Chicago for the U.S. Department of Energy under contract W-31-109-Eng-38. The Laboratory's main facility is outside Chicago, at 9700 South Cass Avenue, Argonne, Illinois 60439. For information about Argonne and its pioneering science and technology programs, see www.anl.gov.

\section{Availability of This Report}

This report is available, at no cost, at http://www.osti.gov/bridge. It is also available on paper to U.S. Department of Energy and its contractors, for a processing fee, from:

U.S. Department of Energy

Office of Scientific and Technical Information

P.O. Box 62

Oak Ridge, TN 37831-0062

phone (865) 576-8401

fax (865) 576-5728

reports@adonis.osti.gov

\section{Disclaimer}

This report was prepared as an account of work sponsored by an agency of the United States Government. Neither the United States Government nor any agency thereof, nor The University of Chicago, nor any of their employees or officers, makes any warranty, express or implied, or assumes any legal liability or responsibility for the accuracy, completeness, or usefulness of any information, apparatus, product, or process disclosed, or represents that its use would not infringe privately owned rights. Reference herein to any specific commercial product, process, or service by trade name, trademark, manufacturer, or otherwise, does not necessarily constitute or imply its endorsement, recommendation, or favoring by the United States Government or any agency thereof. The views and opinions of document authors expressed herein do not necessarily state or reflect those of the United States Government or any agency thereof, Argonne National Laboratory, or The University of Chicago. 


\section{Transient Analyses for the Tajoura Critical Facility with IRT-2M HEU Fuel and IRT-4M LEU Fuel: ANL Independent Verification Results}

by

P.L.Garner and N.A. Hanan

Nuclear Energy Division, Argonne National Laboratory

November 2,2005

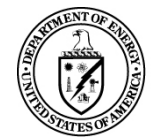




\title{
Transient Analyses for the Tajoura Critical Facility with IRT-2M HEU Fuel and IRT-4M LEU Fuel: ANL Independent Verification Results
}

\author{
P.L. Garner and N. A. Hanan \\ RERTR Program \\ Argonne National Laboratory \\ Argonne, Illinois, USA 60439
}

November 2, 2005

\section{Summary}

Calculations have been performed for postulated transients in the Critical Facility at the Tajoura Nuclear Research Center (TNRC) in Libya. These calculations have been performed at the request of staff of the Renewable Energy and Water Desalinization Research Center (REWDRC) who are performing similar calculations. The transients considered were established during a working meeting between ANL and REWDRC staff on October 1-2, 2005 and subsequent email correspondence. Calculations were performed for the current high-enriched uranium (HEU) core and the proposed low-enriched uranium (LEU) core. These calculations have been performed independently from those being performed by REWDRC and serve as one step in the verification process.

2. General Reactor Information

\subsection{General}

The Critical Facility is a low power physics mockup of the adjacent $10 \mathrm{MW}$ reactor. Nominal power is $1 \mathrm{~W}$, and maximum power is $100 \mathrm{~W}$. The core is located in a tank $2 \mathrm{~m}$ in diameter and $4.5 \mathrm{~m}$ in height. The core is cooled by natural convection of the water in the tank.

\section{2. $\mathrm{HEU}$}

The HEU core map is shown in Figure 2.2.1. The fuel assembly type is IRT-2M. There are 16 fuel assemblies; 10 having 3 fuel tubes and 6 having 4 fuel tubes. The fuel assemblies are set on a pitch of $71.5 \mathrm{~mm}$. The fuel tubes are $2.0 \mathrm{~mm}$ thick, which consists of $0.4 \mathrm{~mm}$ of fuel between two $0.8 \mathrm{~mm}$ thicknesses of cladding. The thickness of the water gap between adjacent fuel tubes is $4.5 \mathrm{~mm}$; the half-thickness of the water space outside of the outermost fuel tube is $2.25 \mathrm{~mm}$. The outermost fuel tube has an outer flat-to-flat measurement of $67.0 \mathrm{~mm}$. The outermost three tubes are the same in 3- and 4-tube fuel assemblies. The innermost tube in the 3-tube assembly has an inner flat-to-flat dimension of $37.0 \mathrm{~mm}$; the innermost tube in the 4-tube assembly has an inner flat-to-flat dimension of $24.0 \mathrm{~mm}$. The radius of the outer surface of the corners of the outermost fuel tube is $10.0 \mathrm{~mm}$; the radius for the outer surface of the corners of an interior fuel tube is $1.0 \mathrm{~mm}$ smaller than the next most outer fuel tube; the radius of the inner surface of a fuel tube corner is $2.0 \mathrm{~mm}$ (i.e., same as 
the tube thickness) less than the radius of the outer surface of the corner. Interior to the innermost fuel tube in the 4-tube assembly is a circular tube having $8.0 \mathrm{~mm}$ outer radius; material interior to this tube is ignored in the transient calculations. Interior to the innermost fuel tube in the 3-tube assembly is a tube having the same outer dimensions as the innermost tube of the 4-tube assembly; material interior to this tube is ignored in the transient calculations since it does not heat up on this time scale.

The neutronics parameters calculated at ANL for this core are shown in the "HEU" column in the tables in Section 2.4.

\subsection{LEU}

The LEU core map is shown in Figure 2.3.1. The fuel assembly type is IRT-4M. There are 16 fuel assemblies; 10 having 6 fuel tubes and 6 having 8 fuel tubes. The fuel tubes have four flat sides joined by rounded corners. The fuel assemblies have the same $71.5 \mathrm{~mm}$ pitch as in the HEU core. The fuel tubes are $1.6 \mathrm{~mm}$ thick, which consists of $0.7 \mathrm{~mm}$ of fuel between two $0.45 \mathrm{~mm}$ thicknesses of cladding. The thickness of the water gap between adjacent fuel tubes is $1.85 \mathrm{~mm}$; the half-thickness of the water space outside of the outermost fuel tube is $0.95 \mathrm{~mm}$. The outermost fuel tube has an outer flat-to-flat measurement of $69.6 \mathrm{~mm}$. The outermost six tubes are the same in 6- and 8-tube fuel assemblies. The innermost tube in the 6-tube assembly has an inner flat-to-flat dimension of $31.9 \mathrm{~mm}$; the innermost tube in the 8-tube assembly is round rather than square and has an inner diameter of $18.1 \mathrm{~mm}$. The radius of the outer surface of the corners of the outermost fuel tube is $9.3 \mathrm{~mm}$; the radius for the outer surface of the corners of an interior fuel tube is $0.8 \mathrm{~mm}$ smaller than the next most outer fuel tube; the radius of the inner surface of a fuel tube corner is $1.6 \mathrm{~mm}$ (i.e., same as the plate thickness) less than the radius of the outer surface of the corner. Interior to the innermost fuel tube in the 8-tube assembly is a circular tube having $14.0 \mathrm{~mm}$ outer diameter; material interior to this tube is ignored in the transient calculations. Interior to the innermost fuel tube in the 6-tube assembly is a tube having the same outer dimensions as the next-to-innermost tube of the 8-tube assembly; material interior to this tube is ignored in the transient calculations since it does not heat up on this time scale.

The neutronics parameters calculated at ANL for this core are shown in the "LEU" column of the tables in Section 2.4

\subsection{HEU and LEU Comparison and Summary}

The MCNP code was used to calculate [Ref. 1] the shutdown margin, individual worth of control rods, detailed power distribution, and various other neutronics parameters for the HEU and LEU cores. The results are shown in Table 2.4.1, 2.4.2, 2.4.3, etc. Whenever needed, the rod worth curves in Table 2.4. $\mathrm{x}$ and Figure 2.4.1 are assumed to be piecewise linear between the actual points for which worths were calculated.

3. Specific Transients

\subsection{Common Conditions}


The maximum normal operating power for the facility is $100 \mathrm{~W}$. There is only natural convection cooling of the core; the coolant flow rate was assumed to be equivalent to an average velocity of $1.15 \mathrm{~mm} / \mathrm{s}$ (or $1.15 \mathrm{~kg} / \mathrm{m}^{2}-\mathrm{s}$ ) for the HEU core and $0.54 \mathrm{~mm} / \mathrm{s}$ (or $0.54 \mathrm{~kg} / \mathrm{m}^{2}-\mathrm{s}$ ) for the LEU core, based on results from NATCON [Ref. 2] at $100 \mathrm{~W}$ and $25^{\circ} \mathrm{C}$ inlet temperature.

An overpower trip occurs at $112 \mathrm{~W}$ (i.e., $12 \%$ overpower). In the facility there is also a trip on period being less than $20 \mathrm{~s}$. There is assumed to be a delay time of $0.1 \mathrm{~s}$ between attaining any trip condition and start of control rod motion. A control rod is assumed to travel from fully withdrawn (i.e., $+0.336 \mathrm{~m}$ ) to fully inserted (i.e., $-0.312 \mathrm{~m}$ ) in $0.6 \mathrm{~s}$; the motion of the rods is assumed to occur at a constant velocity of $1.08 \mathrm{~m} / \mathrm{s}(=(0.336+0.312) / 0.6)$. (For comparison, the free fall of an object would require approximately $0.35 \mathrm{~s}$ to cover the 0.58 to $0.6 \mathrm{~m}$ heights of these cores.) All transient calculations were started with the reactor critical which mean the control rods are located as follows: rods $\mathrm{KC}-3, \mathrm{KC}-4, \mathrm{KC}-5, \mathrm{KC}-6$ (in the center of the core) and AR are fully inserted; rods AZ-1 and AZ-2 are fully withdrawn; and rods $\mathrm{KC}-1, \mathrm{KC}-2, \mathrm{KC}-7$, and $\mathrm{KC}-8$ are $39 \mathrm{~mm}$ above the core center in the HEU core and $59 \mathrm{~mm}$ below the core center for the LEU core. Therefore, scram consists of the drop of the two AZ rods from fully withdrawn position and the drop of four $\mathrm{KC}$ rods from approximately mid-core height. As shown in Table 3.1.1, the sum of these insertable rod worths is $13.25 \$$ in the HEU core and 9.39 \$ in the LEU core. This reactivity is assumed to be introduced non-linearly in time by each rod falling from its initial position at a constant velocity of $1.08 \mathrm{~m} / \mathrm{s}$; the resulting reactivity insertion versus time is shown for both cores in Table 3.1.2.

All transient calculations were performed using Version 7.5h of PARET [Ref. 3]. The basic geometry in PARET is a "channel", which consists of a half-thickness fuel plate and the adjacent half-thickness water gap. Various channels may be modeled in parallel to represent the reactor core. The present work used two channels: one for the fuel plate containing the highest power density and a second channel to represent the rest of the reactor core.

\subsection{Transient T1: Control Rod Withdrawal}

\subsubsection{Boundary Conditions}

The transient is defined as the withdrawal of the highest worth control rod at a constant speed of $3.5 \mathrm{~mm} / \mathrm{s}$. There is a little ambiguity as to what should be considered the highest worth rod. Two cases are possible for each core. The highest worth rod is KC-6 in both the HEU and LEU cores; these rods are fully inserted at critical. The movement of a fully inserted control rod has a small initial effect but could have a large integrated effect over the length of the transient. A more severe transient may be due to the movement of the highest worth partly-inserted rod, which is $\mathrm{KC}-7$ at $39 \mathrm{~mm}$ above core center plane in the $\mathrm{HEU}$ core and is $\mathrm{KC}-7$ at $59 \mathrm{~mm}$ below the core center plane in the LEU core. The $3.5 \mathrm{~mm} / \mathrm{s}$ rod motion rate combined with the rod's initial position is used in conjunction with the rod's relative worth curve (cf. Fig. 2.4.1) and total worth to obtain a reactivity change as a function of time. The resulting boundary condition values are shown in Table 3.2.1.1 and Figure 3.2.1.1. If scram occurs before $60 \mathrm{~s}$ in the HEU case 
when using rod $\mathrm{KC}-7$; then that will be the most severe case; otherwise, the case should be rerun using rod KC-6. If scram occurs before $85 \mathrm{~s}$ in the LEU case when using rod $\mathrm{KC}-7$, then that will be the most severe case; otherwise, the case should be rerun using rod $\mathrm{KC}-6$.

\subsubsection{Results}

The results computed using PARET for this transient in the HEU core are shown in Figures 3.2.2.1 through 3.2.2.3. The power increases from $100 \mathrm{~W}$ to the $112 \mathrm{~W}$ scram limit in $3.54 \mathrm{~s}$; the rods start moving into the core $0.1 \mathrm{~s}$ later at which time the power has reached $112.4 \mathrm{~W}$. During this time the peak clad temperature has increase by less than $0.0001^{\circ} \mathrm{C}$. The scram reactivity terminates the transient before any damage can be done. As shown in Figure 3.2.2.3, the period stays above $20 \mathrm{~s}$ up until the time of scram, so the period scram setting does not provide an earlier termination of the transient. Since the high power scram occur before $60 \mathrm{~s}$ then rod $\mathrm{KC}-7$ was the worst rod to move.

The results computed using PARET for this transient in the LEU core are shown in Figures 3.2.2.4 through 3.2.2.6. The power increases from $100 \mathrm{~W}$ to the $112 \mathrm{~W}$ scram limit in $3.19 \mathrm{~s}$. During this time the peak clad temperature has increase by less than $0.0001^{\circ} \mathrm{C}$. The scram reactivity terminates the transient before any damage can be done. As shown in Figure 3.2.2.6, the period stays above $20 \mathrm{~s}$ up until the time of scram, so the period scram setting does not provide an earlier termination of the transient. Since the high power scram occur before $60 \mathrm{~s}$ then rod $\mathrm{KC}-7$ was the worst rod to move.

\subsection{Transient T2: Control Rod Withdrawal Combined with $100 \mathrm{~mm}$ Step Withdrawal of Another Control Rod}

\subsubsection{Boundary Conditions}

This "ramp plus step" transient is defined as (a) the withdrawal of the highest worth control rod at a constant speed of $3.5 \mathrm{~mm} / \mathrm{s}$ (i.e., same as in Sec. 3.2) plus (b) a $100 \mathrm{~mm}$ step withdrawal (such as might be caused by a sudden mechanical impact on the control rod drive line cable) of the second highest worth control rod. Boundary condition for part a is the same as used in Sec. 3.2.1. As before, "highest worth" and "second highest worth" are assumed to refer to the rods which are at least partly inserted into the core at the beginning of the transient.

For part $\mathrm{b}$, the $0.1 \mathrm{~m}$ motion inserts the largest amount of reactivity for a rod whose tip is near the core center rather than for a fully inserted rod. The second highest worth partly inserted rod in the HEU core is KC-8 (assuming KC-7 is used for part a); moving this rod $100 \mathrm{~mm}$ upward from its critical position of $39 \mathrm{~mm}$ above core center results in a reactivity insertion of $0.608 \$$ (which is a fractional rod worth of 0.213 times a total rod worth of $2.86 \$$ ). The second highest worth partly inserted rod in the LEU core is KC-1 (assuming KC-7 is used for part a); moving this rod $100 \mathrm{~mm}$ upward from its critical position of $59 \mathrm{~mm}$ below core center results in a reactivity insertion of $0.695 \$$ (which is 
a fractional rod worth of 0.266 times a total rod worth of $2.61 \$$ ). The step insertions is added over $0.01 \mathrm{~s}$ in the simulation calculations and is added to the rod withdrawal reactivities shown in Table 3.2.1.1.

\subsubsection{Results}

The results computed using PARET for this transient in the HEU core are shown in Figures 3.3.2.1 through 3.3.2.3. The power increases from $100 \mathrm{~W}$ to the $112 \mathrm{~W}$ scram limit in $0.007 \mathrm{~s}$; the rods start moving into the core $0.1 \mathrm{~s}$ later at which time the power has reached $248 \mathrm{~W}$. During this time the peak clad temperature has increase by less than $0.0001^{\circ} \mathrm{C}$. The scram reactivity terminates the transient before any damage can be done. As shown in Figure 3.3.2.3, the period is below $20 \mathrm{~s}$ for the entire transient (due to the step insertion from the $100 \mathrm{~mm}$ rod motion), which would result in a slightly earlier scram and even lower temperature increase.

The results computed using PARET for this transient in the LEU core are shown in Figures 3.3.2.4 through 3.3.2.6. The power increases from $100 \mathrm{~W}$ to the $112 \mathrm{~W}$ scram limit in $0.007 \mathrm{~s}$; the rods start moving into the core $0.1 \mathrm{~s}$ later at which time the power has reached $318 \mathrm{~W}$. During this time the peak clad temperature has increase by less than $0.0001^{\circ} \mathrm{C}$. The scram reactivity terminates the transient before any damage can be done. As shown in Figure 3.3.2.6, the period is below $20 \mathrm{~s}$ for the entire transient (due to the step insertion from the $100 \mathrm{~mm}$ rod motion), which would result in a slightly earlier scram and even lower temperature increase.

Since this case reaches the highest power of the transients being considered, a series of modified cases was run based on this case.

\subsubsection{Modified Case T2.1: Initial Power of $1 \mathrm{~W}$}

Since the critical facility is run at other powers less than $100 \mathrm{~W}$, the ramp plus step reactivity insertion case was run at a lower initial power of $1 \mathrm{~W}$. The cases were calculated at a correspondingly lower coolant flow rate: $0.11 \mathrm{~mm} / \mathrm{s}$ in the HEU core and $0.05 \mathrm{~mm} / \mathrm{s}$ in the LEU core, based on results from NATCON at $1 \mathrm{~W}$ power and $25^{\circ} \mathrm{C}$ inlet temperature.

The power in the HEU core increases from $1 \mathrm{~W}$ to $112 \mathrm{~W}$ in $5.87 \mathrm{~s}$; the rods start moving into the core $0.1 \mathrm{~s}$ later at which time the power has reached $122 \mathrm{~W}$. During this time the peak clad temperature has increase by less than $0.0003^{\circ} \mathrm{C}$. The scram reactivity terminates the transient before any damage can be done. The period is below $20 \mathrm{~s}$ for the entire transient (due to the step insertion from the $100 \mathrm{~mm}$ rod motion), which would result in a earlier scram and even lower temperature increase.

The power in the LEU core increases from $1 \mathrm{~W}$ to $112 \mathrm{~W}$ in $3.74 \mathrm{~s}$; the rods start moving into the core $0.1 \mathrm{~s}$ later at which time the power has reached $126 \mathrm{~W}$. During this time the peak clad temperature has increase by less than $0.0001^{\circ} \mathrm{C}$. The scram reactivity terminates the transient before any damage can be done. The period is below $20 \mathrm{~s}$ for the 
entire transient (due to the step insertion from the $100 \mathrm{~mm}$ rod motion), which would result in a earlier scram and even lower temperature increase.

\subsubsection{Modified Case T2.2: Coolant Flow Rate of $50 \mathrm{~kg} / \mathrm{m}^{2}-\mathrm{s}$}

The critical facility is believed to be cooled with just natural convection of the water. There appears to be purification system for the water having a pump which circulates water at a flow rate of $8 \mathrm{~m}^{3} / \mathrm{h}$. An additional case has been calculated assuming this purification flow rate of water is forced upward through the fuel assemblies; the equivalent mass flux is $50 \mathrm{~kg} / \mathrm{m}^{2}-\mathrm{s}$, which is significantly higher than the values of 0.5 to $1.1 \mathrm{~kg} / \mathrm{m}^{2}$-s computed using NATCON for natural circulation. (This mass flux value is based on the LEU core geometry, but the same value was used for the HEU core.)

The primary change is that the temperatures are lower at steady state; using peak cladding temperature in the hot channel at steady state as a basis, the value is $25.05^{\circ} \mathrm{C}$ for forced flow and $25.67^{\circ} \mathrm{C}$ for natural circulation in the HEU core and is $25.02^{\circ} \mathrm{C}$ for forced flow and $27.31^{\circ} \mathrm{C}$ for natural circulation in the LEU core. The high power scram, the peak power, its timing, and the increase in temperature during the ramp plus step reactivity transient are unaffected by using a higher flow rate in these scrammed transients in the HEU and LEU cores.

\subsection{Fall of the Aluminum Follower for Control Rod}

\subsubsection{Boundary Conditions}

This transient is initiated by the detachment and downward motion of the aluminum control rod follower from the bottom end of partially withdrawn control rod KC-7. The relative worth of the follower is shown in Table 3.4.1.1 and Figure 3.4.1.1. For the HEU core, the top of the rod follower is initially $12 \mathrm{~mm}$ above the core center; it is assumed to fall to $291 \mathrm{~mm}$ below core center at the same $1.08 \mathrm{~m} / \mathrm{s}$ velocity as the control rod drop during scram; this requires a time of $0.28 \mathrm{~s}$ and inserts a positive reactivity of $0.119 \$$, which is inserted linearly over the elapsed time. For the LEU core, the top of the rod follower is initially $86 \mathrm{~mm}$ below the core center; it is assumed to fall to $291 \mathrm{~mm}$ below core center at the same $1.08 \mathrm{~m} / \mathrm{s}$ velocity as the control rod drop during scram; this requires a time of $0.19 \mathrm{~s}$ and inserts a positive reactivity of $0.151 \$$, which is inserted linearly over the elapsed time. (As will be seen, the drop time is sufficiently short relative to the length of the transient that this can be considered a step insertion of reactivity.)

\subsubsection{Results}

The results computed using PARET for this transient in the HEU core are shown in Figures 3.4.2.1 through 3.4.2.3. The power increases from $100 \mathrm{~W}$ to the $112 \mathrm{~W}$ scram limit in $0.256 \mathrm{~s}$; the rods start moving into the core $0.1 \mathrm{~s}$ later at which time the power has reached $113.9 \mathrm{~W}$. During this time the peak clad temperature has increased by less than 
$0.0001^{\circ} \mathrm{C}$. The scram reactivity terminates the transient before any damage can be done. As shown in Figure 3.4.2.3, the period is below $20 \mathrm{~s}$ for the entire transient, which would provide a slightly earlier termination of the transient.

The results computed using PARET for this transient in the LEU core are shown in Figures 3.4.2.4 through 3.4.2.6. The power increases from $100 \mathrm{~W}$ to the $112 \mathrm{~W}$ scram limit in $0.14 \mathrm{~s}$; the rods start moving into the core $0.1 \mathrm{~s}$ later at which time the power has reached $118 \mathrm{~W}$. During this time the peak clad temperature has increased by less than $0.0001^{\circ} \mathrm{C}$. The scram reactivity terminates the transient before any damage can be done. As shown in Figure 3.4.2.6, the period is below $20 \mathrm{~s}$ for the entire transient, which would provide slightly earlier termination of the transient.

\subsection{Drop of Fuel Assembly into Corner Position}

This transient is defined as the drop of a fuel assembly toward the corner position of a core having 15 fuel assemblies in place. After being proposed, the REWDRC and ANL have agreed via email correspondence that this is not a transient of interest for the following reasons. Fuel assembly movement operations are only performed when all KC and AR rods are fully inserted in the core. As noted in Table 2.4.2, both cores with all 16 fuel assemblies loaded and all $\mathrm{KC}$ and AR rods fully inserted are highly subcritical (by $6.21 \%$ for HEU and $3.35 \%$ for LEU); therefore, dropping a $16^{\text {th }}$ assembly toward a core containing 15 assemblies with the KC and AR rods fully inserted does not produce a critical configuration in either core. Additionally, when a fuel assembly is not in one of the 16 core positions its place is filled with an aluminum displacer in order to maintain proper core positioning; the presence of this displacer would prevent a dropped assembly from actually entering its normal core position.

\section{Conclusions}

Calculations have been performed for the requested transients in HEU and LEU cores in the Critical Facility at TNRC. The scram system is assumed to be operable for all transients. Because of this, all transients are terminated by either high power or low period within a few seconds of initiation, at which time there is essentially no increase in temperature above normal operating values. The LEU core responds slightly faster than does the HEU core, likely due to the differences in neutron generation time for the two cores.

\section{References}

1. N. A. Hanan, personal communications, Argonne National Laboratory (October 7, 2005).

2. R. S. Smith and W. L. Woodruff, "A Computer Code, NATCON, for the Analyses of Steady-State Thermal-Hydraulics and Safety Margins in Plate-Type Research Reactors 
Cooled by Natural Convection", ANL/RERTR/TM-12, Argonne National Laboratory (December 1988).

3. Arne P. Olson, "A Users Guide to the PARET/ANL V7.0 Code", Argonne National Laboratory (April 20, 2005); Woodruff, W.L., "A User's Guide for the ANL Version of the PARET Code", National Energy Software Center, Argonne, Illinois (1984); and Obenchain, C.F., "PARET - A Program for the Analysis of Reactor Transients", IDO17282, AEC Research and Development Report, Phillips Petroleum Company (January 1969). 


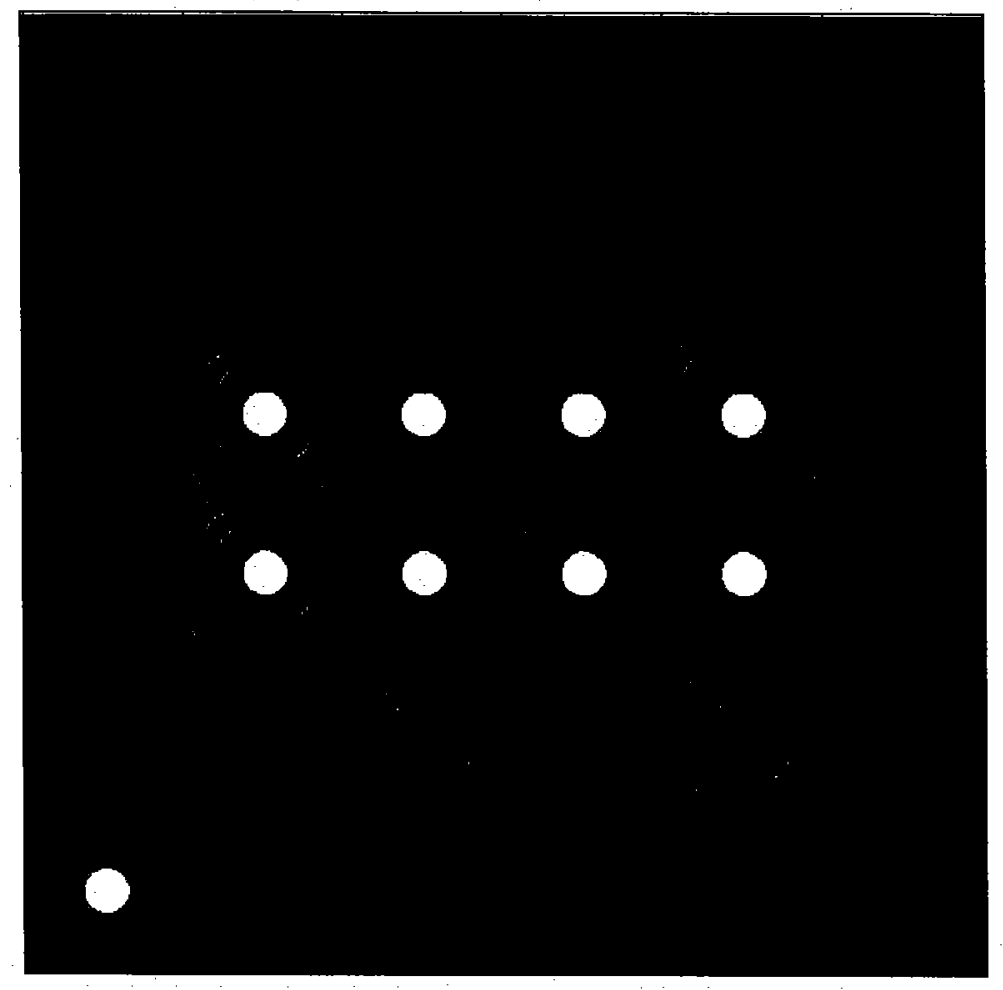

Figure 2.2.1 HEU Core: Ten 3-tube and Six 4-tube IRT-2M Fuel Assemblies

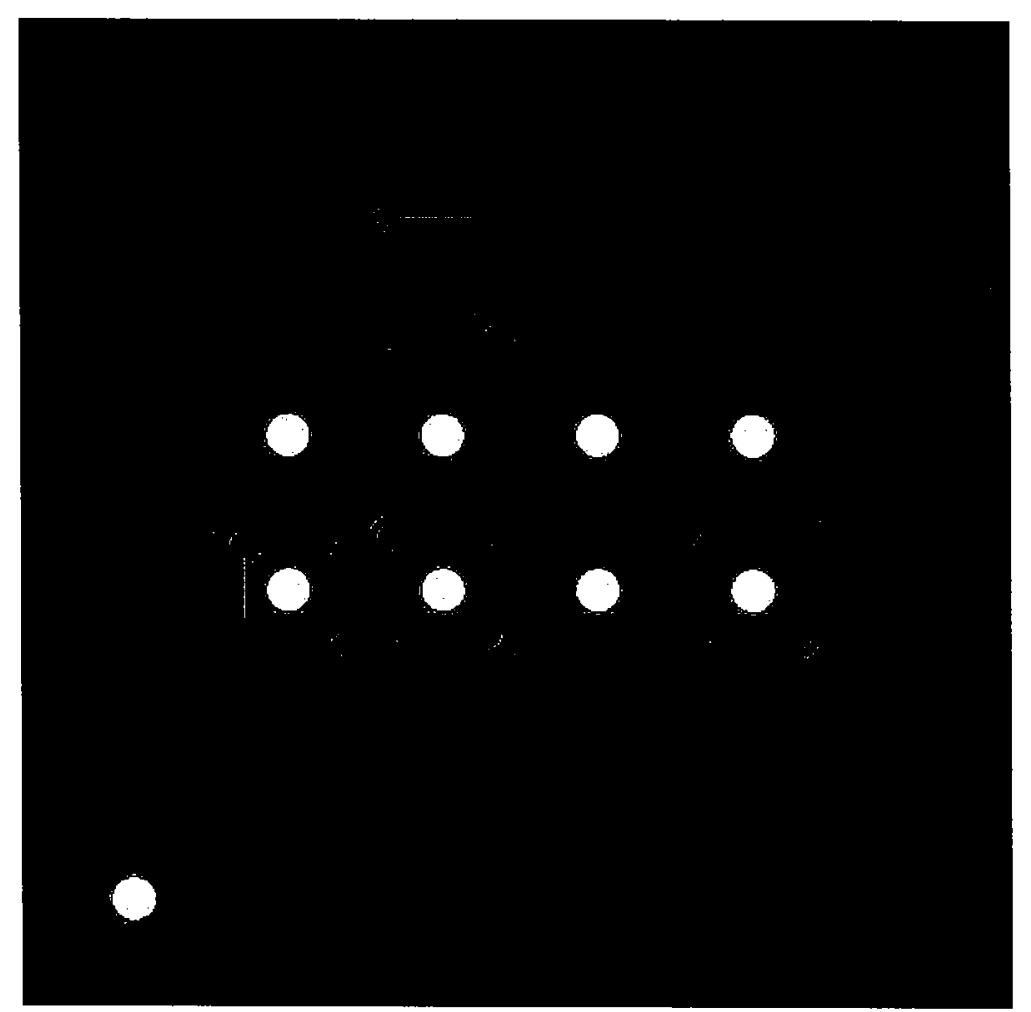

Figure 2.3.1 LEU Core: Ten 6-tube and Six 8-tube IRT-4M Fuel Assemblies 
Table 2.4.1 Neutronic Parameters for HEU and LEU Cores

\begin{tabular}{|c|c|c|}
\hline & HEU Core & LEU Core \\
\hline Effective Delayed Neutron Fraction, $\beta_{\text {eff }}$ & $7.64 \mathrm{e}-3 \pm 5.64 \mathrm{e}-5$ & $7.69 \mathrm{e}-3 \pm 5.64 \mathrm{e}-5$ \\
\hline Neutron Generation Time, $\Lambda$ [us] & $93.0 \pm 1.5$ & $79.9 \pm 1.5$ \\
\hline \multicolumn{3}{|l|}{$\begin{array}{l}\text { Moderator Temperature Reactivity } \\
\text { Coefficient, } \Delta \rho / \Delta \mathrm{T}[\% / \mathrm{K}] \text { : }\end{array}$} \\
\hline $294 \mathrm{~K}$ to $400 \mathrm{~K}$ & $-1.70 \mathrm{e}-2 \pm 5.09 \mathrm{e}-5$ & $-1.01 e-2 \pm 4.75 e-5$ \\
\hline $400 \mathrm{~K}$ to $600 \mathrm{~K}$ & $-1.67 \mathrm{e}-2 \pm 3.03 \mathrm{e}-5$ & $-1.05 e-2 \pm 2.95 e-5$ \\
\hline $294 \mathrm{~K}$ to $600 \mathrm{~K}$ & $-1.68 \mathrm{e}-2 \pm 1.75 \mathrm{e}-5$ & $-1.04 \mathrm{e}-2 \pm 1.70 \mathrm{e}-5$ \\
\hline \multicolumn{3}{|l|}{$\begin{array}{l}\text { Fuel Temperature (Doppler) Reactivity } \\
\text { Coefficient, } \Delta \rho / \Delta \mathrm{T}[\% / \mathrm{K}] \text { : }\end{array}$} \\
\hline $294 \mathrm{~K}$ to $400 \mathrm{~K}$ & negligible & $-2.02 \mathrm{e}-3 \pm 4.71 \mathrm{e}-5$ \\
\hline $400 \mathrm{~K}$ to $600 \mathrm{~K}$ & negligible & $-2.09 e-3 \pm 2.93 e-5$ \\
\hline $294 \mathrm{~K}$ to $600 \mathrm{~K}$ & negligible & $-2.07 e-3 \pm 1.66 e-5$ \\
\hline \multicolumn{3}{|l|}{$\begin{array}{l}\text { Moderator Density (Void) Reactivity } \\
\text { Coefficient, } \Delta \rho / \Delta \alpha \text { [\%/\% of void]: }\end{array}$} \\
\hline 0 to $5 \%$ & $-2.07 \mathrm{e}-1 \pm 8.93 \mathrm{e}-4$ & $-2.90 \mathrm{e}-1 \pm 1.01 \mathrm{e}-3$ \\
\hline $5 \%$ to $10 \%$ & $-2.34 \mathrm{e}-1 \pm 1.17 \mathrm{e}-3$ & $-3.14 \mathrm{e}-1 \pm 1.19 \mathrm{e}-3$ \\
\hline 0 to $10 \%$ & $-2.21 \mathrm{e}-1 \pm 5.29 \mathrm{e}-4$ & $-3.02 \mathrm{e}-1 \pm 5.19 \mathrm{e}-4$ \\
\hline
\end{tabular}

Table 2.4.2 Control Rod Information

\begin{tabular}{|l|l|l|}
\hline & \multicolumn{1}{|c|}{ HEU Core } & LEU Core \\
\hline $\begin{array}{l}\text { Shutdown Margin with all KC and AR } \\
\text { Rods Inserted [\%] }\end{array}$ & -6.21 & -3.35 \\
\hline Control Rod Worths [\%]: ([\$]) & & \\
\hline KC-1 & $2.163(2.83)$ & $2.011(2.61)$ \\
\hline KC-2 & $2.146(2.81)$ & $2.004(2.61)$ \\
\hline KC-3 & $2.858(3.74)$ & $2.474(3.22)$ \\
\hline KC-4 & $2.850(3.73)$ & $2.467(3.21)$ \\
\hline KC-5 & $2.852(3.73)$ & $2.461(3.20)$ \\
\hline KC-6 & $2.896(3.79)$ & $2.479(3.22)$ \\
\hline KC-7 & $2.190(2.87)$ & $2.041(2.65)$ \\
\hline KC-8 & $2.185(2.86)$ & $2.000(2.60)$ \\
\hline AZ-1 & $2.303(3.01)$ & $2.120(2.76)$ \\
\hline AZ-2 & $2.320(3.04)$ & $2.172(2.82)$ \\
\hline AZ-1 plus AZ-2 & $5.236(6.85)$ & $4.772(6.20)$ \\
\hline AR & $0.278(0.36)$ & $0.331(0.43)$ \\
\hline Critical Rod Position [mm rel. to ctr] & +39 & -59 \\
\hline Relative Control Rod Worth [-] & & \\
\hline$+336 \mathrm{~mm}$ & 0 & 0 \\
\hline$+236 \mathrm{~mm}$ & 0.0392 & 0.0430 \\
\hline$+136 \mathrm{~mm}$ & 0.1585 & 0.1726 \\
\hline$+36 \mathrm{~mm}$ (above core center) & 0.3733 & 0.3846 \\
\hline$-64 \mathrm{~mm}$ (below core center) & 0.6648 & 0.6494 \\
\hline$-164 \mathrm{~mm}$ & 0.8920 & 0.8895 \\
\hline$-264 \mathrm{~mm}$ & 0.9944 & 0.9892 \\
\hline$-312 \mathrm{~mm}$ & 1.0 & 1.0 \\
\hline
\end{tabular}

1. Position is for rods $\mathrm{KC}-1,-2,-3,-4$. Rods $\mathrm{KC}-3,-4,-5,-6$ and $\mathrm{AR}$ are fully inserted. Rods AZ-1,-2 are fully out. 


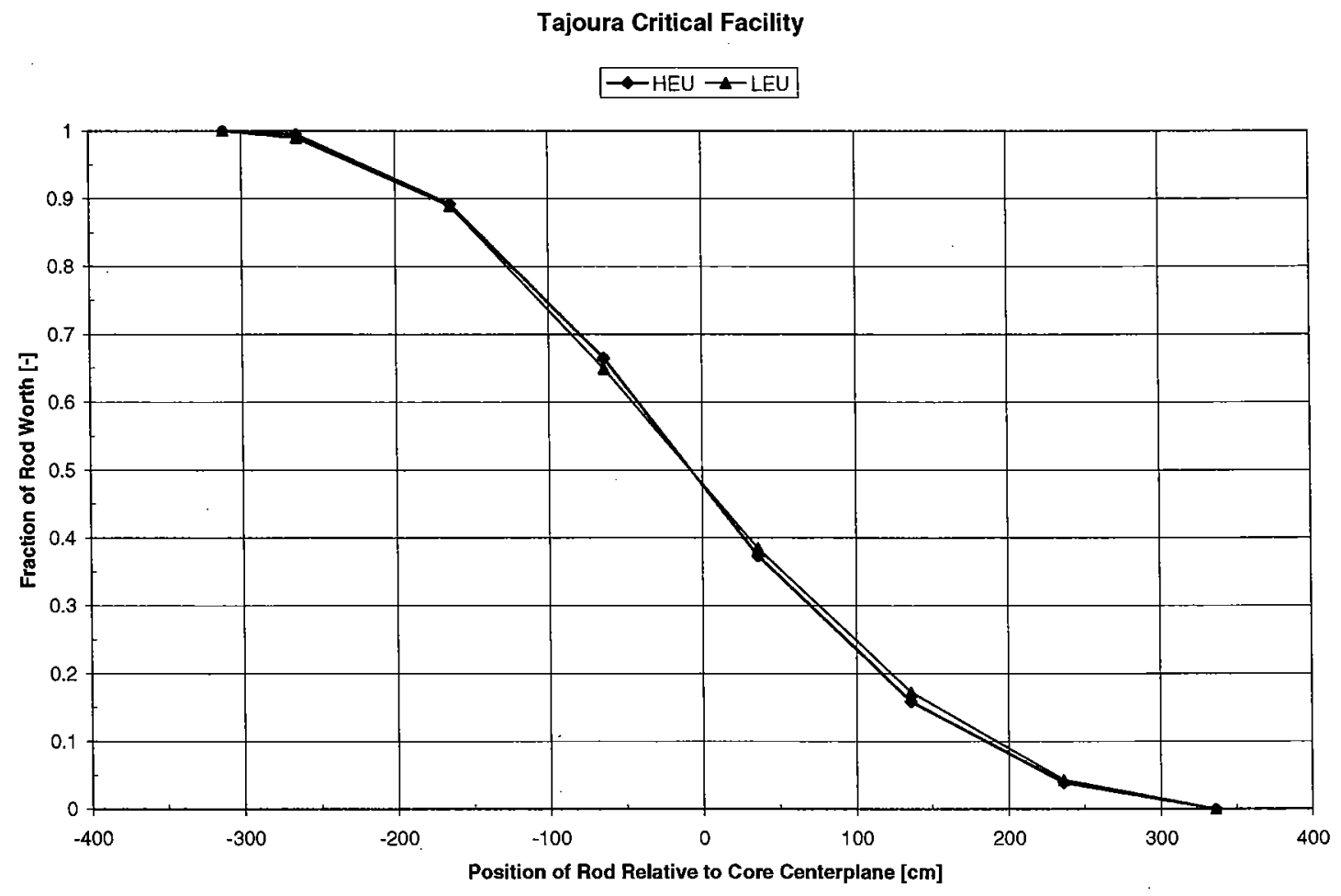

Figure 2.4.1 Relative Control Rod Worth versus Axial Position (“S-curve”)

Table 2.4.3 Delayed Neutron Group Characteristics (Generic; not computed for TNRC Critical)

\begin{tabular}{|l|l|l|}
\hline Group & Fraction [-] & Decay $[1 / \mathrm{s}]$ \\
\hline 1 & 0.0351 & $1.33 \mathrm{e}-2$ \\
\hline 2 & 0.1804 & $3.27 \mathrm{e}-2$ \\
\hline 3 & 0.1743 & $1.21 \mathrm{e}-1$ \\
\hline 4 & 0.3840 & $3.03 \mathrm{e}-1$ \\
\hline 5 & 0.1595 & $8.50 \mathrm{e}-1$ \\
\hline 6 & 0.0667 & $2.86 \mathrm{e}+0$ \\
\hline
\end{tabular}


Table 3.1.1 Scram Reactivity

\begin{tabular}{|l|l|l|l|l|}
\hline & \multicolumn{2}{|c|}{ HEU } & \multicolumn{2}{c|}{ LEU } \\
\hline & $\begin{array}{l}\text { Initial Position } \\
{[\mathrm{mm}]}\end{array}$ & $\begin{array}{l}\text { Insertable Worth } \\
{[\%(\$)]}\end{array}$ & $\begin{array}{l}\text { Initial Position } \\
{[\mathrm{mm}]}\end{array}$ & $\begin{array}{l}\text { Insertable Worth } \\
{[\%(\$)]}\end{array}$ \\
\hline KC-1 & +39 & $1.369(1.79)$ & -59 & $0.730(0.95)$ \\
\hline KC-2 & +39 & $1.359(1.78)$ & -59 & $0.730(0.95)$ \\
\hline KC-7 & +39 & $1.388(1.82)$ & -59 & $0.741(0.96)$ \\
\hline KC-8 & +39 & $1.383(1.81)$ & -59 & $0.727(0.95)$ \\
\hline AZ-1 & +336 & $2.300(3.01)$ & +336 & $2.122(2.76)$ \\
\hline AZ-2 & +336 & $2.323(3.04)$ & +336 & $2.169(2.82)$ \\
\hline Total & & $10.122(13.25)$ & & $7.220(9.39)$ \\
\hline & & & & \\
\hline
\end{tabular}

1. Relative rod worth at $+39 \mathrm{~mm}$ in HEU core is 0.633 and at $-59 \mathrm{~mm}$ in LEU core is 0.364 .

Table 3.1.2 Inserted Control Rod Worth During Scram

\begin{tabular}{|c|c|c|c|c|c|c|c|}
\hline & $\mathrm{HEl}$ & & & & $\overline{\mathrm{LE}}$ & & \\
\hline Time $[\mathrm{s}]$ & Rod Position & {$[\mathrm{mm}]$} & Inserted & Time [s] & Rod Position & {$[\mathrm{mm}]$} & Inserted \\
\hline & $\mathrm{KC}-1,2,7,8$ & AZ-1,2 & Worth [\$] & & $\mathrm{KC}-1,2,7,8$ & AZ-1,2 & Worth [\$] \\
\hline 0 & 39 & 336 & 0 & 0 & -59 & 336 & 0 \\
\hline 0.05 & -15 & 282 & -1.89 & 0.05 & -113 & 282 & -1.50 \\
\hline 0.10 & -69 & 228 & -3.81 & 0.10 & -167 & 228 & -2.98 \\
\hline 0.15 & -123 & 174 & -5.60 & 0.15 & -221 & 174 & -3.94 \\
\hline 0.20 & -177 & 120 & -7.29 & 0.20 & -275 & 120 & -4.87 \\
\hline 0.25 & -231 & 66 & -8.62 & 0.234 & -312 & 83 & -5.40 \\
\hline 0.30 & -285 & 12 & -9.84 & 0.25 & -312 & 66 & -5.60 \\
\hline 0.325 & -312 & -15 & -10.36 & 0.30 & -312 & 12 & -6.31 \\
\hline 0.35 & -312 & -42 & -10.83 & 0.35 & -312 & -42 & -7.11 \\
\hline 0.40 & -312 & -96 & -11.66 & 0.40 & -312 & -96 & -7.86 \\
\hline 0.45 & -312 & -150 & -12.40 & 0.45 & -312 & -150 & -8.58 \\
\hline 0.50 & -312 & -204 & -12.84 & 0.50 & -312 & -204 & -9.00 \\
\hline 0.55 & -312 & -258 & -13.18 & 0.55 & -312 & -258 & -9.30 \\
\hline 0.60 & -312 & -312 & -13.25 & 0.60 & -312 & -312 & -9.39 \\
\hline
\end{tabular}


Table 3.2.1.1 Reactivity Insertion for Rod Withdrawal Transient T1

\begin{tabular}{|l|l|r|l|l|r|l|}
\hline Withdraw Highest Worth Partly Inserted Rod: \\
\hline Core & \multicolumn{3}{|c|}{ HEU } & \multicolumn{3}{c|}{ KC-7 } \\
\hline Rod & \multicolumn{3}{|c|}{ KC-7 } \\
\hline & $\begin{array}{l}\text { Time } \\
{[\mathrm{s}]}\end{array}$ & $\begin{array}{l}\text { Position } \\
{[\mathrm{mm}]}\end{array}$ & $\begin{array}{l}\text { Reactivity } \\
{[\$]}\end{array}$ & $\begin{array}{l}\text { Time } \\
{[\mathrm{s}]}\end{array}$ & $\begin{array}{l}\text { Position } \\
{[\mathrm{mm}]}\end{array}$ & $\begin{array}{l}\text { Reactivity } \\
{[\$]}\end{array}$ \\
\hline & 0 & 39 & 0 & 0 & -59 & 0 \\
\hline & 27.71 & 136 & 0.598 & 27.14 & 36 & 0.667 \\
\hline & 56.29 & 236 & 0.940 & 55.71 & 136 & 1.228 \\
\hline & 84.86 & 336 & 1.053 & 84.29 & 236 & 1.572 \\
\hline & & & & 112.86 & 336 & 1.686 \\
\hline
\end{tabular}

\begin{tabular}{|l|l|r|l|l|r|l|}
\hline \multicolumn{7}{|c|}{ Withdraw Highest Worth Fully Inserted Rod: } \\
\hline Core & \multicolumn{3}{|c|}{ HEU } & \multicolumn{3}{c|}{ LEU } \\
\hline Rod & \multicolumn{3}{|c|}{ KC-6 } \\
\hline & $\begin{array}{l}\text { Time } \\
{[\mathrm{s}]}\end{array}$ & $\begin{array}{l}\text { Position } \\
{[\mathrm{mm}]}\end{array}$ & $\begin{array}{l}\text { Reactivity } \\
{[\$]}\end{array}$ & $\begin{array}{l}\text { Time } \\
{[\mathrm{s}]}\end{array}$ & $\begin{array}{l}\text { Position } \\
{[\mathrm{mm}]}\end{array}$ & $\begin{array}{l}\text { Reactivity } \\
{[\$]}\end{array}$ \\
\hline & 0 & -312 & 0 & 0 & -312 & 0 \\
\hline & 13.71 & -264 & 0.021 & 13.71 & -264 & 0.035 \\
\hline & 42.29 & -164 & 0.409 & 42.29 & -164 & 0.356 \\
\hline & 70.86 & -64 & 1.270 & 70.86 & -64 & 1.129 \\
\hline & 99.43 & 36 & 2.375 & 99.43 & 36 & 1.982 \\
\hline & 128.00 & 136 & 3.189 & 128.00 & 136 & 2.664 \\
\hline & 156.57 & 236 & 3.641 & 156.57 & 236 & 3.082 \\
\hline & 185.14 & 336 & 3.790 & 185.14 & 336 & 3.220 \\
\hline
\end{tabular}

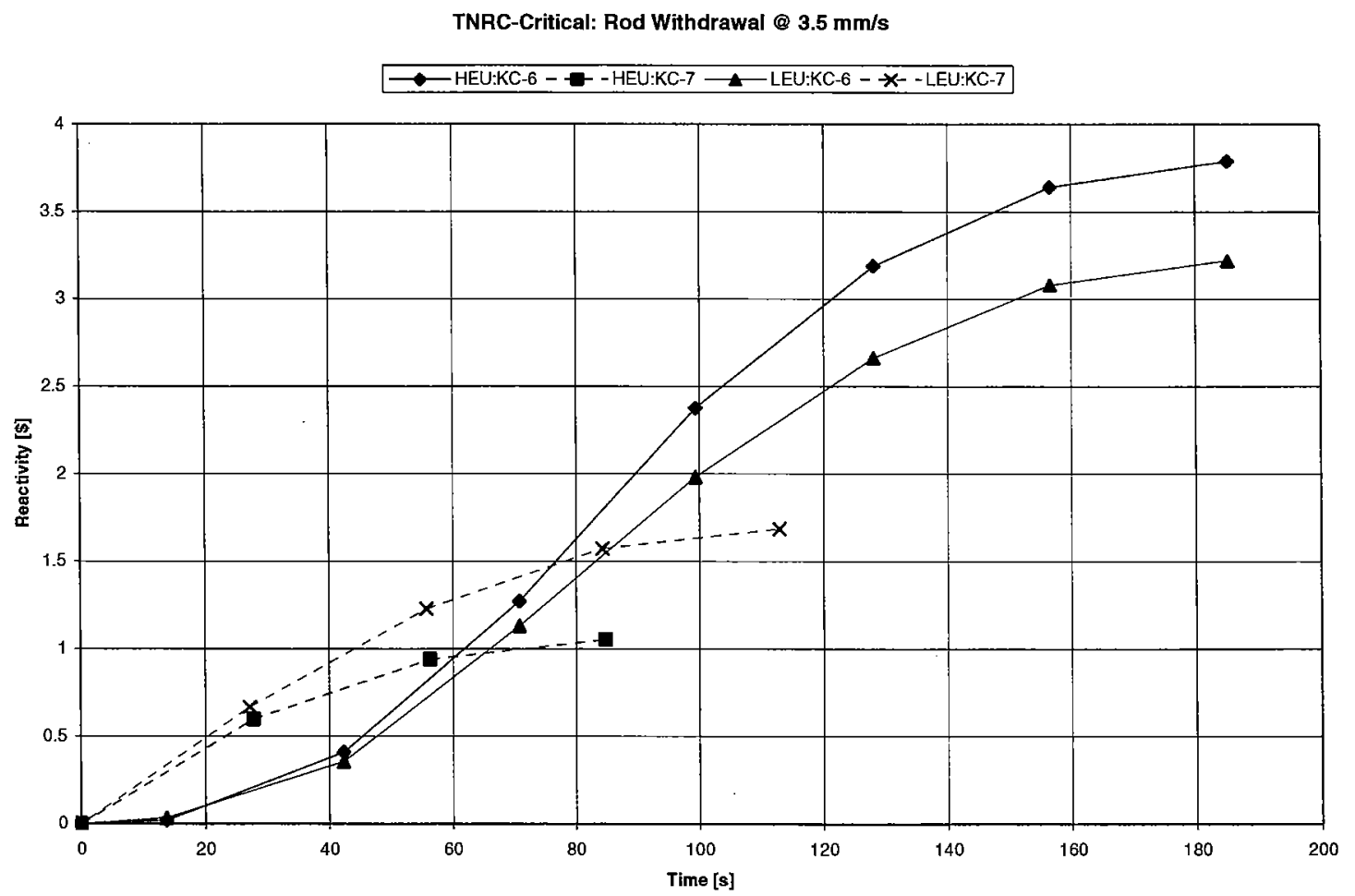




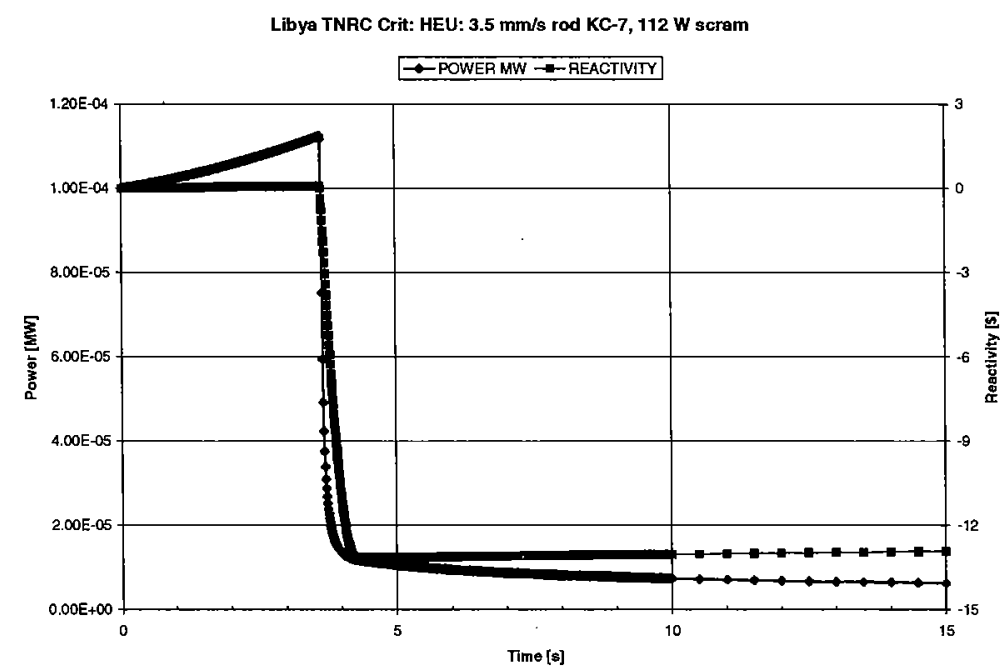

Figure 3.2.2.1 Power and Net Reactivity for $3.5 \mathrm{~mm} / \mathrm{s}$ Control Rod Withdrawal in HEU Core

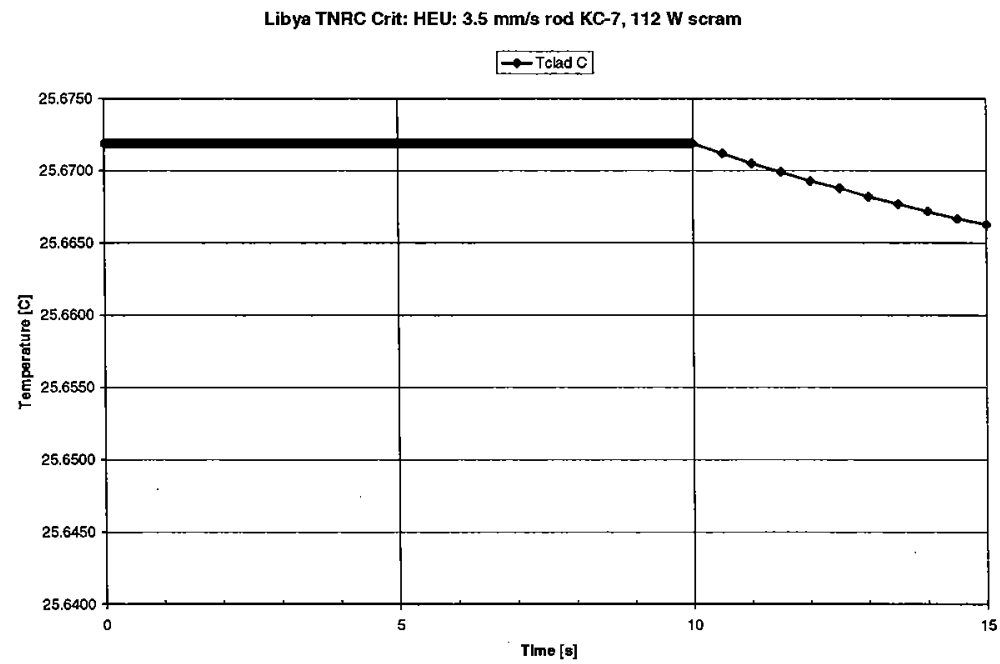

Figure 3.2.2.2 Peak Clad Temperature in Hot Channel for $3.5 \mathrm{~mm} / \mathrm{s}$ Rod Withdrawal in HEU Core Libya TNRC Crit: HEU: $3.6 \mathrm{~mm} / \mathrm{s}$ rod KC-7, $112 \mathrm{~W}$ scram

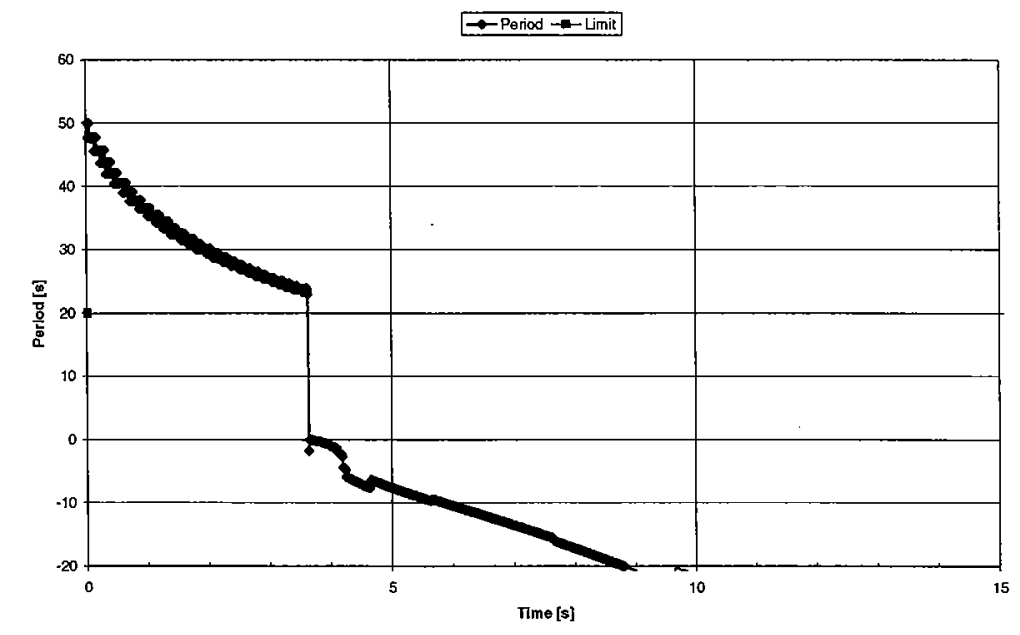

Figure 3.2.2.3 Reactor Period for $3.5 \mathrm{~mm} / \mathrm{s}$ Rod Withdrawal in HEU Core 


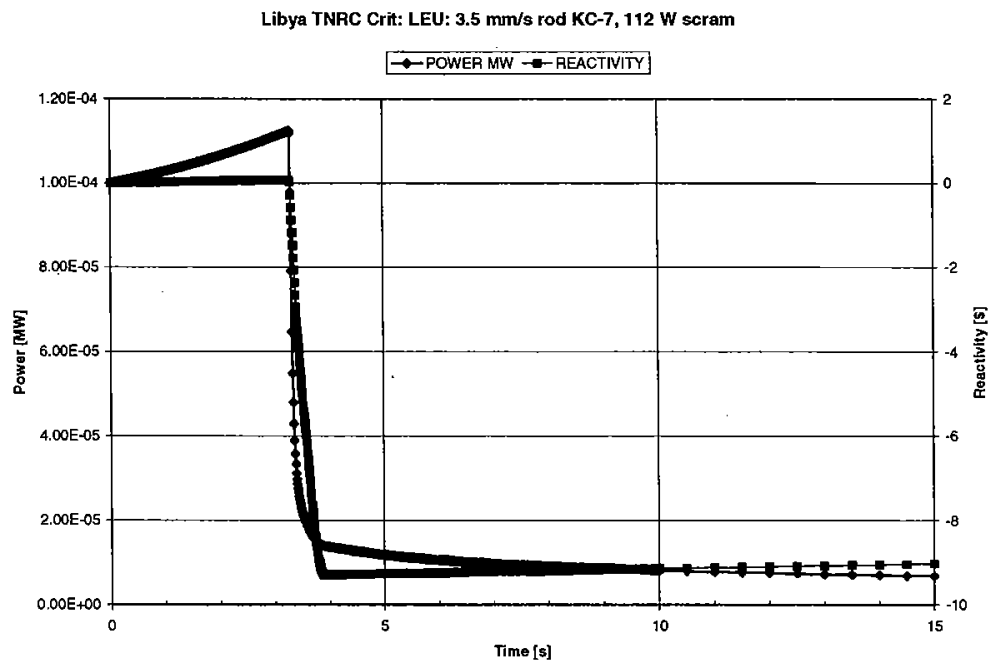

Figure 3.2.2.4 Power and Net Reactivity for $3.5 \mathrm{~mm} / \mathrm{s}$ Control Rod Withdrawal in LEU Core

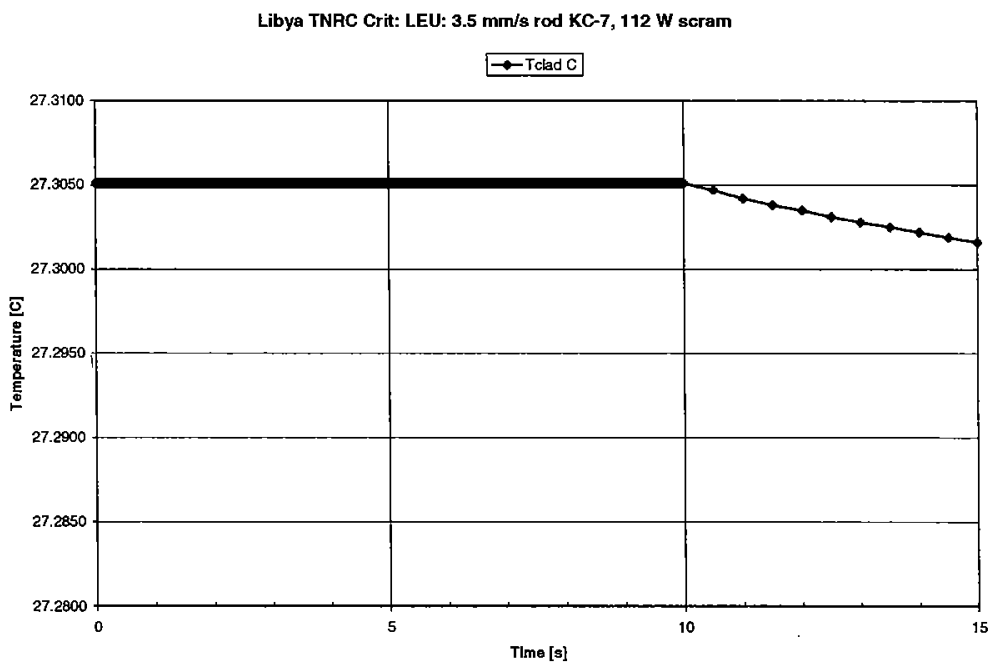

Figure 3.2.2.5 Peak Clad Temperature in Hot Channel for $3.5 \mathrm{~mm} / \mathrm{s}$ Rod Withdrawal in LEU Core

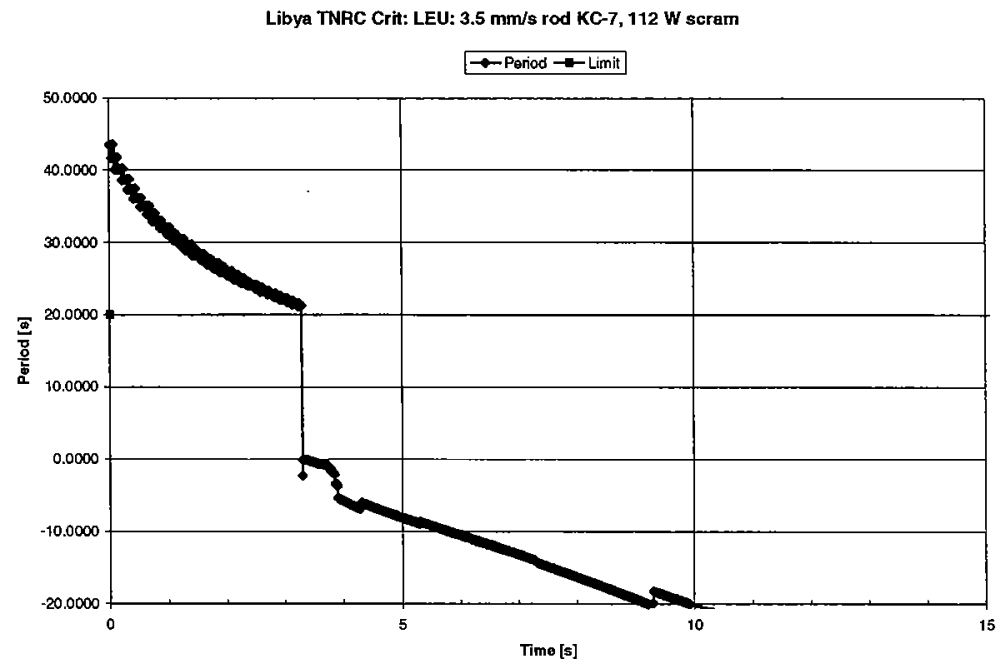

Figure 3.2.2.6 Reactor Period for $3.5 \mathrm{~mm} / \mathrm{s}$ Rod Withdrawal in LEU Core 


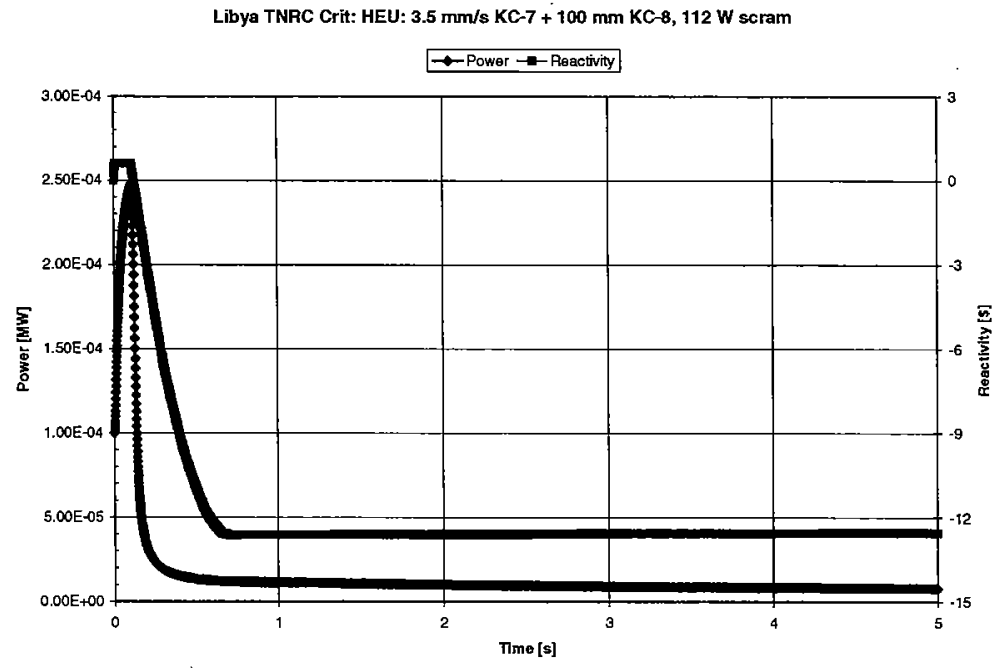

Figure 3.3.2.1 Power for $3.5 \mathrm{~mm} / \mathrm{s}$ Withdraw plus $100 \mathrm{~mm}$ Step in HEU Core Libya TNAC Crit: HEU: $3.5 \mathrm{~mm} / \mathrm{s} \mathrm{KC-7}+100 \mathrm{~mm}$ KC-8, $112 \mathrm{~W}$ scram $\rightarrow-$ Telad C

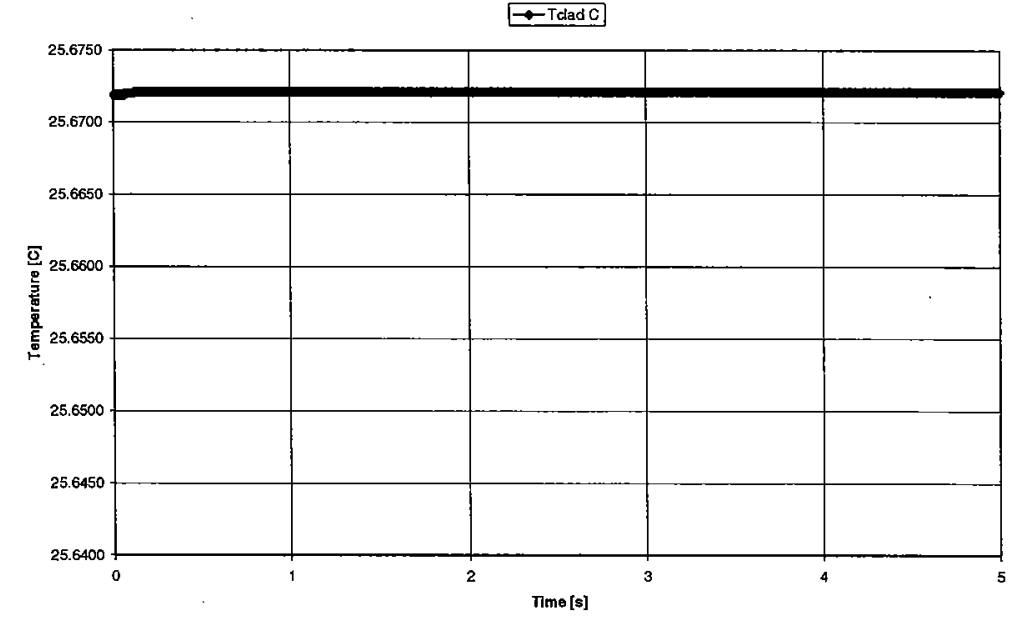

Figure 3.3.2.2 Peak Clad Temperature for $3.5 \mathrm{~mm} / \mathrm{s}$ Withdraw plus $100 \mathrm{~mm}$ Step in HEU Core

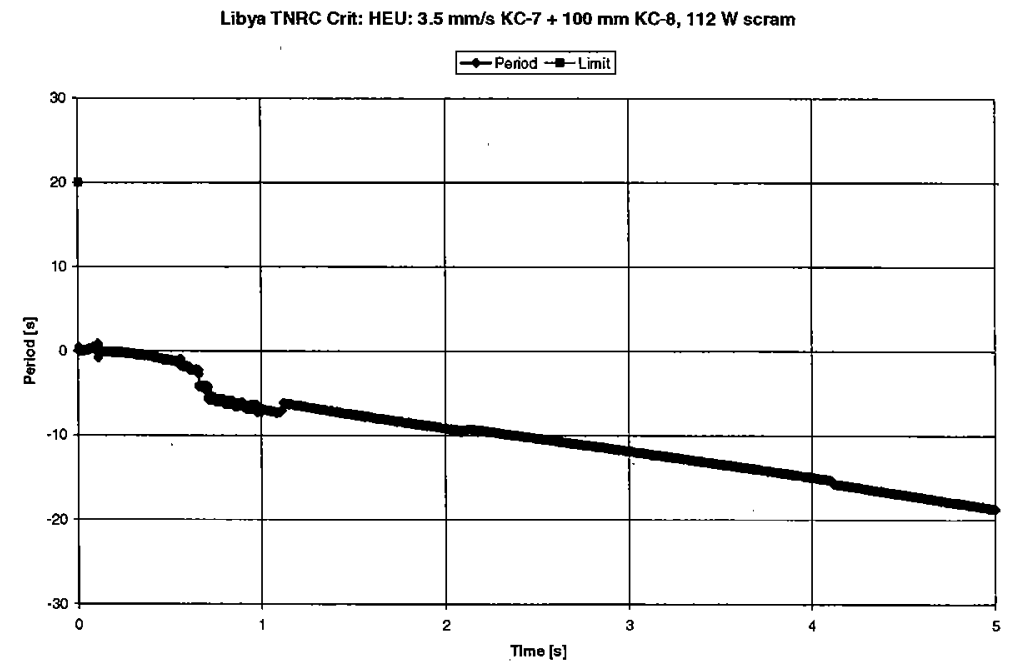

Figure 3.3.2.3 Period for $3.5 \mathrm{~mm} / \mathrm{s}$ Withdraw plus $100 \mathrm{~mm}$ Step in HEU Core 


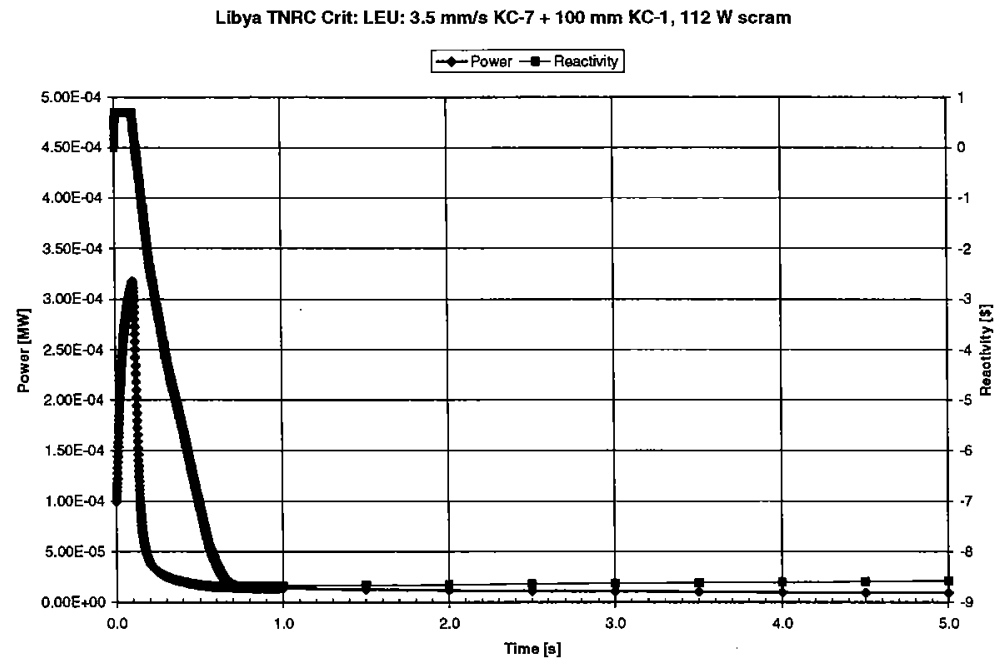

Figure 3.3.2.4 Power for $3.5 \mathrm{~mm} / \mathrm{s}$ Withdraw plus $100 \mathrm{~mm}$ Step in LEU Core

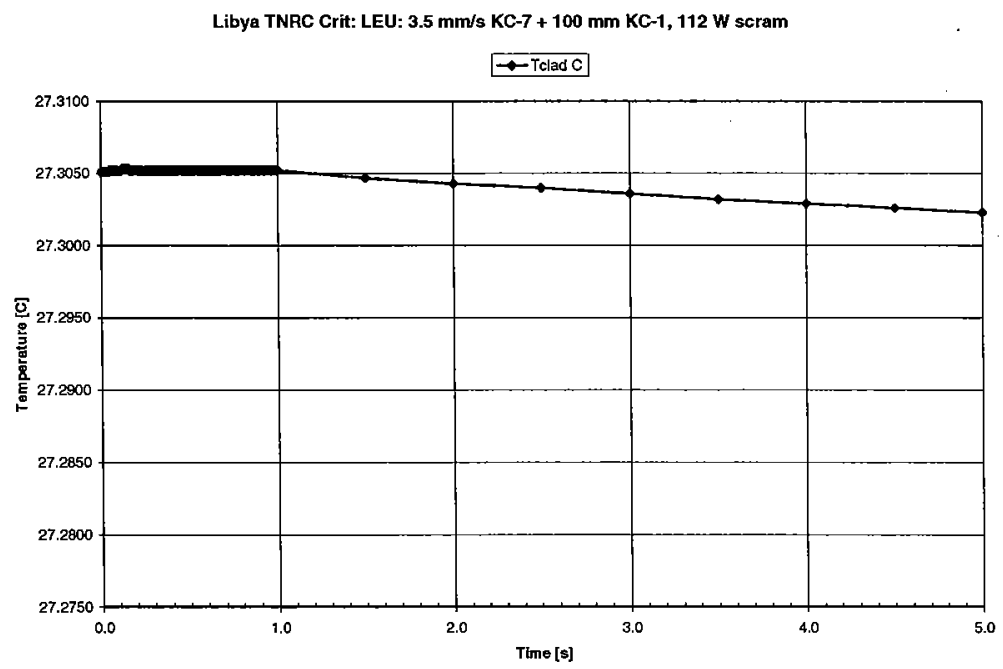

Figure 3.3.2.5 Peak Clad Temperature for $3.5 \mathrm{~mm} / \mathrm{s}$ Withdraw plus $100 \mathrm{~mm}$ Step in LEU Core

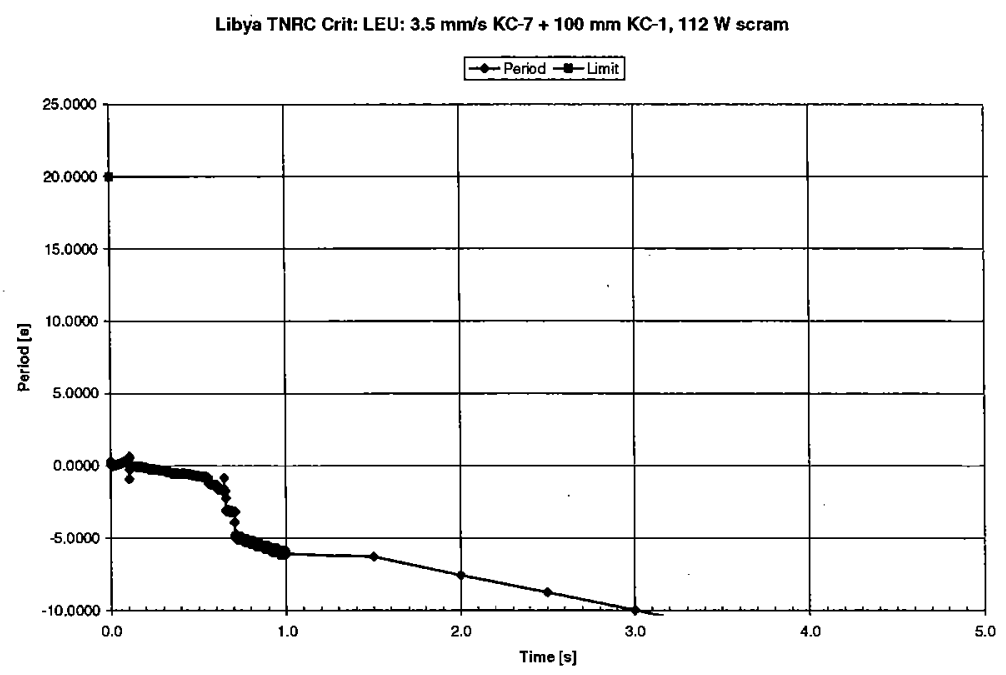

Figure 3.3.2.6 Period for $3.5 \mathrm{~mm} / \mathrm{s}$ Withdraw plus $100 \mathrm{~mm}$ Step in LEU Core 
Table 3.4.1.1 Positional Worth of Rod Follower

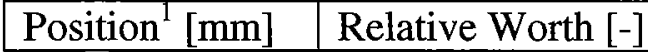

\begin{tabular}{|r|l|}
\hline 309 & 0 \\
\hline 209 & 0.026 \\
\hline 109 & 0.198 \\
\hline-91 & 0.646 \\
\hline-191 & 0.857 \\
\hline-291 & 0.990 \\
\hline-400 & 1 \\
\hline
\end{tabular}

1. Position is of top of follower.

Libya TNRC Crit: Worth of Control Rod Follower When Replaced by Water

$\rightarrow-$ Worth Curve $\square$-HEU-start $\Delta$ LEU-start

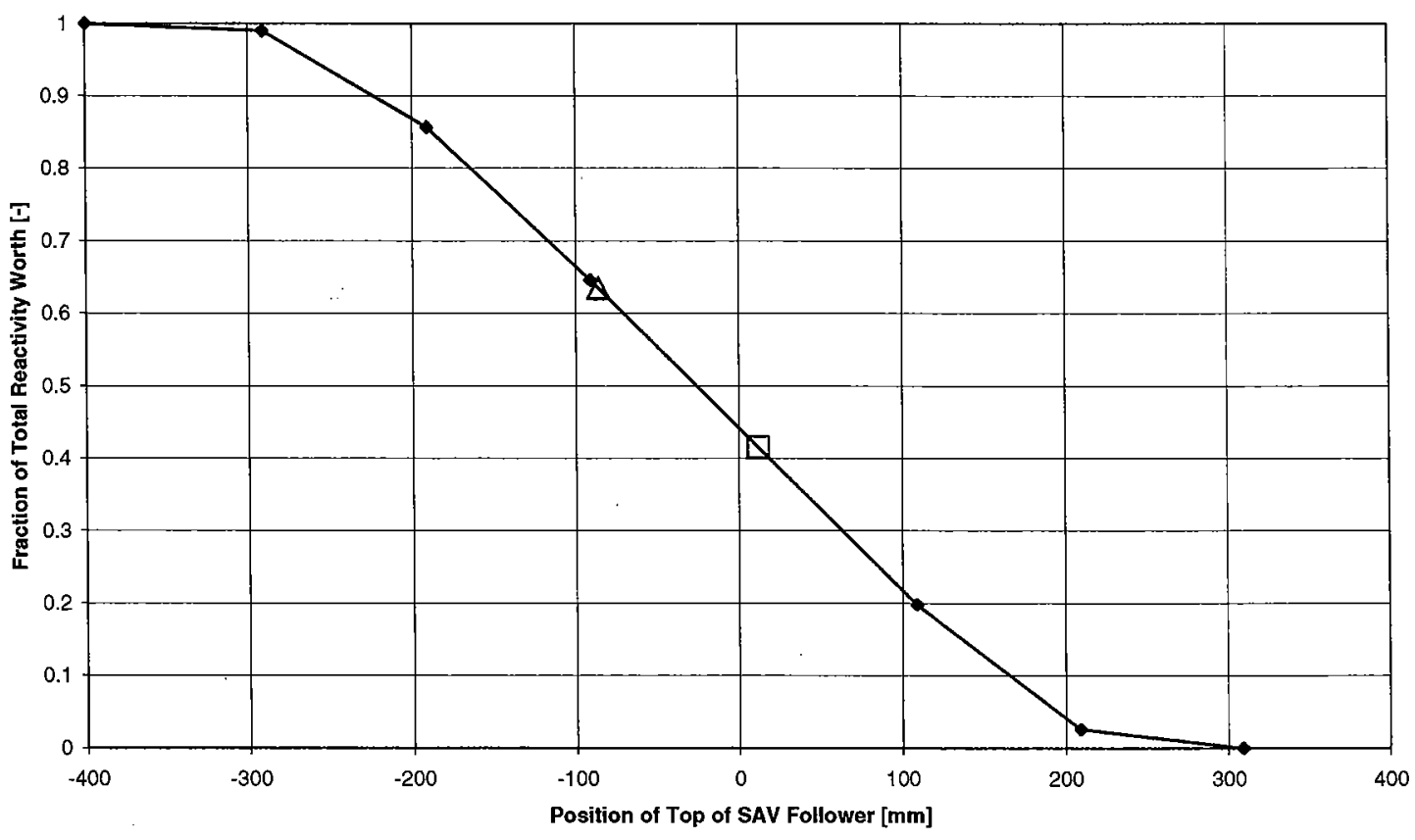

Figure 3.4.1.1 Positional Worth of Control Rod Follower When Replaced by Water 


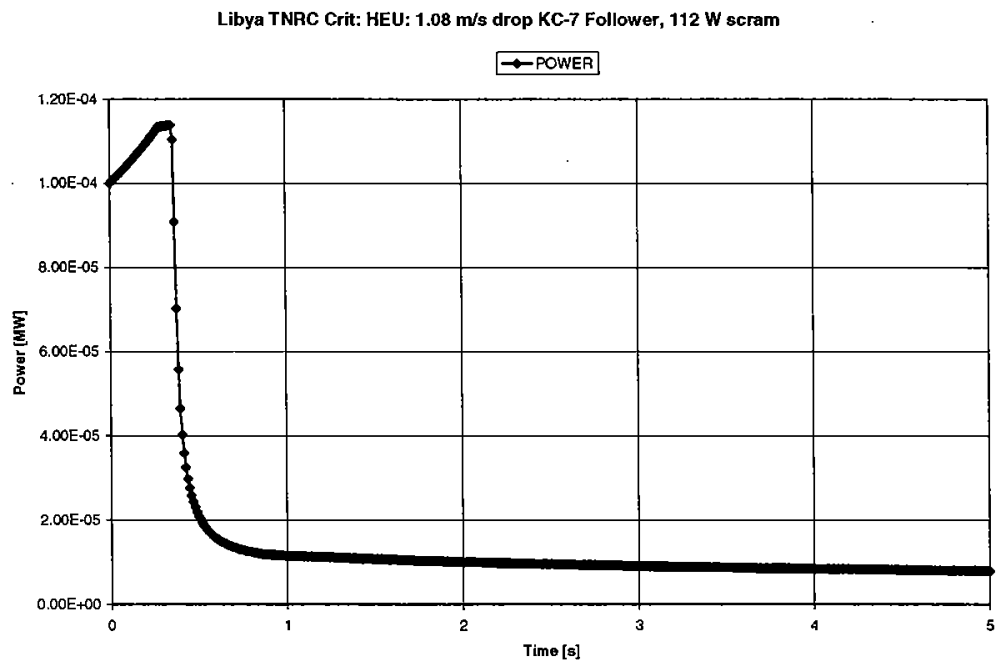

Figure 3.4.2.1 Power for $1.08 \mathrm{~m} / \mathrm{s}$ Rod Follower Drop in HEU Core

Libya TNRC Crit: HEU: $1.08 \mathrm{~m} / \mathrm{s}$ drop KC-7 Follower, $112 \mathrm{~W}$ scram

$\rightarrow-$ Tclad

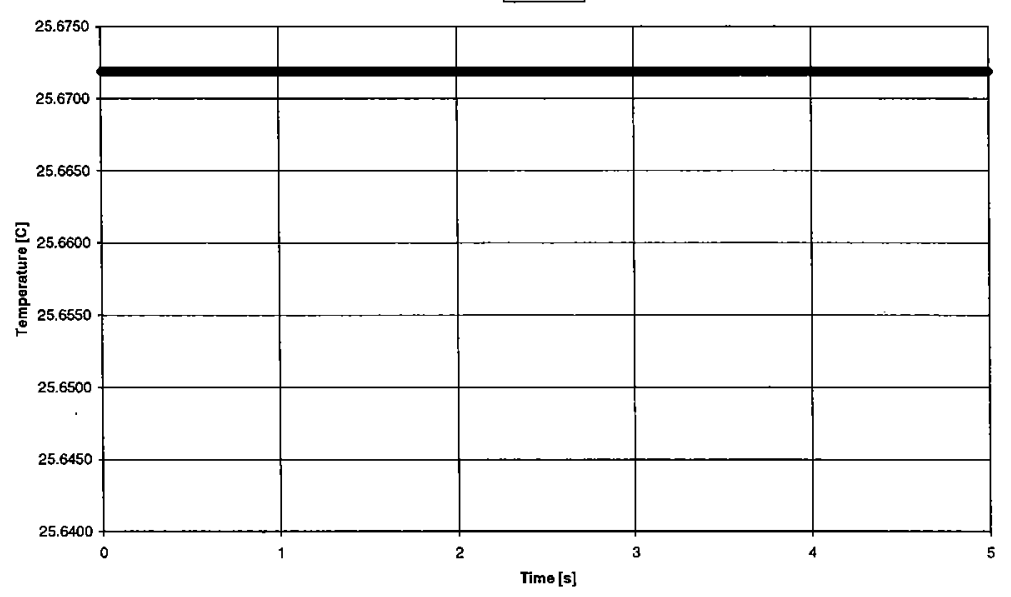

Figure 3.4.2.2 Peak Clad Temperature for $1.08 \mathrm{~m} / \mathrm{s}$ Rod Follower Drop in HEU Core

Libya TNRC Crit: HEU: $1.08 \mathrm{~m} / \mathrm{s}$ drop KC-7 Follower, $112 \mathrm{~W}$ scram

G-Period -E-Limit

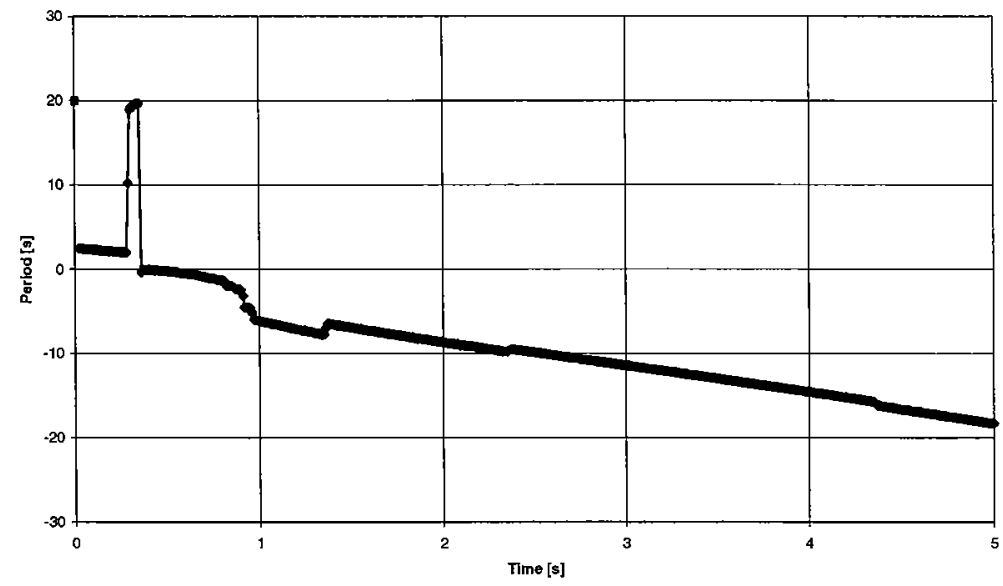

Figure 3.4.2.3 Reactor Period for $1.08 \mathrm{~m} / \mathrm{s}$ Rod Follower Drop in HEU Core 


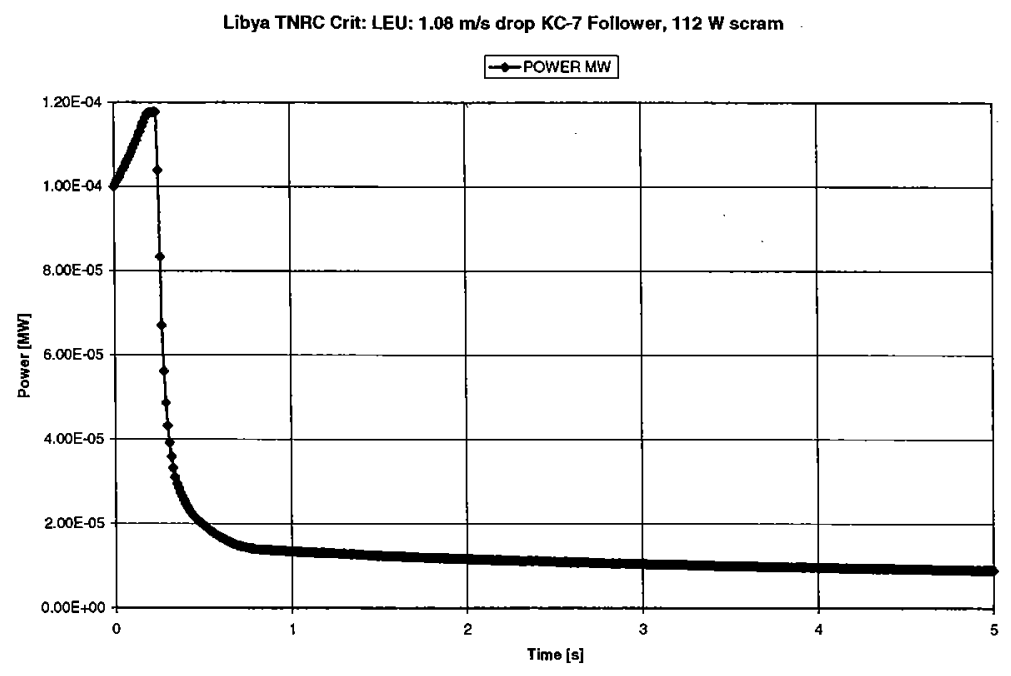

Figure 3.4.2.4 Power for $1.08 \mathrm{~m} / \mathrm{s}$ Rod Follower Drop in LEU Core

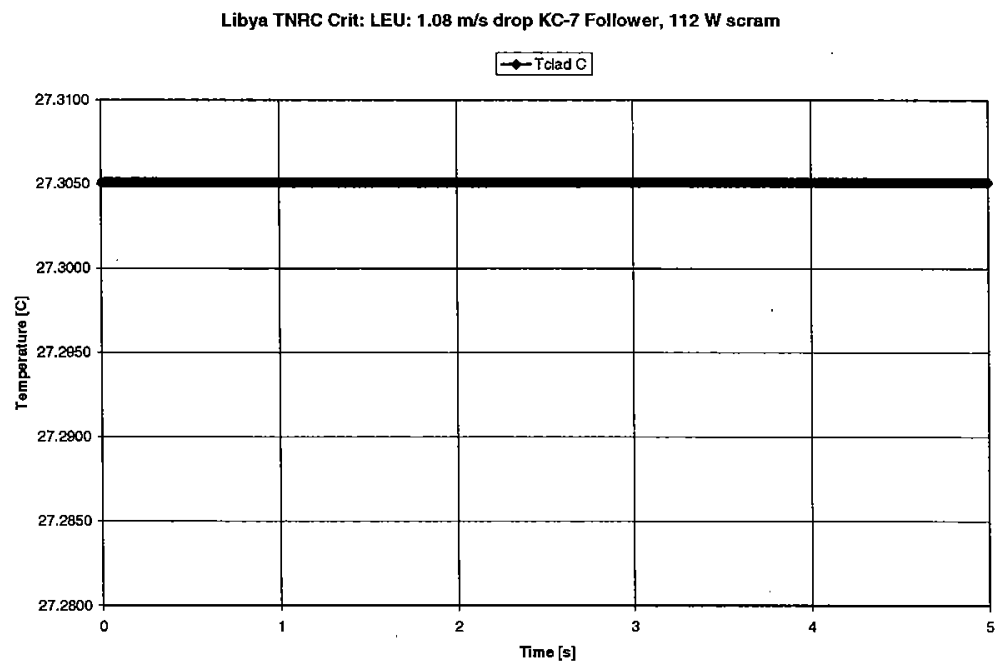

Figure 3.4.2.5 Clad Temperature for $1.08 \mathrm{~m} / \mathrm{s}$ Rod Follower Drop in LEU Core

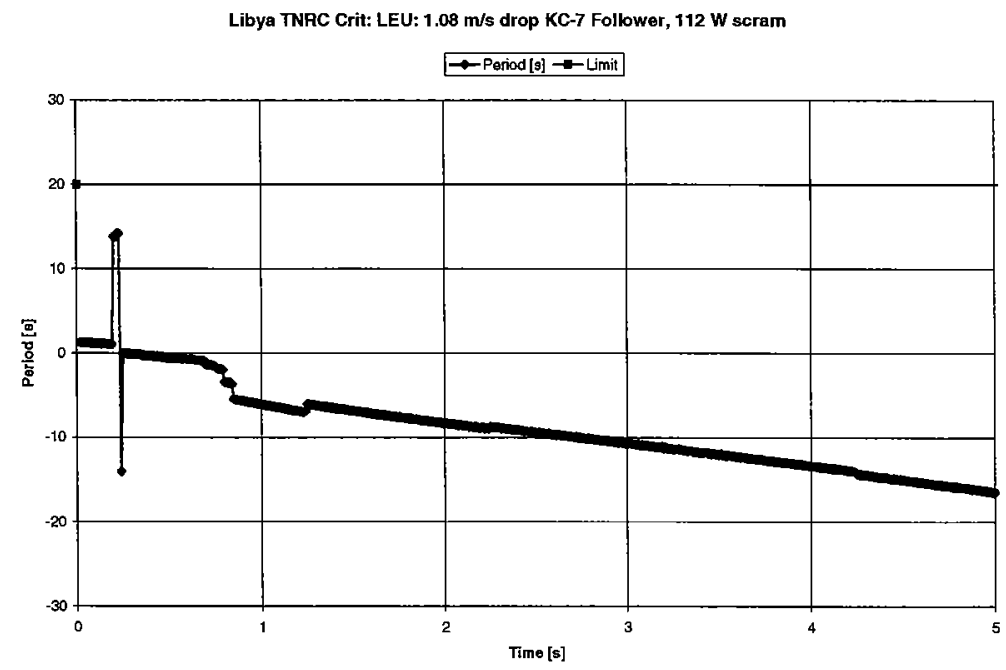

Figure 3.4.2.6 Reactor Period for $1.08 \mathrm{~m} / \mathrm{s}$ Rod Follower Drop in LEU Core 